\title{
Factors Influencing Javanese Krama Language Maintenance by Ampelgading Community in Blitar East Java
}

\author{
Roosi Rusmawati ${ }^{1}$, Ismatul Khasanah ${ }^{2}$, Khilmi Mauliddian ${ }^{3}$ \\ \{roosi_rusmawati@ub.ac.id ${ }^{1}$, ismatulkh@ub.ac.id², khilmi.mauliddian@ub.ac.id ${ }^{3}$ \} \\ Universitas Brawijaya, Indonesia ${ }^{1,2,3}$
}

\begin{abstract}
The purpose of this study was to determine the factors that influence the maintenance of Javanese Krama language by native speakers of the Ampelgading village community which is located at the eastern end of the Blitar border. The method used in this research is qualitative, which is to provide an overview of a situation as clearly as possible without any treatment to the object under study. This research is based on this sociolinguistic study to obtain data on linguistic phenomena that exist in society. The result concludes that there are specifically five factors influencing the maintenance of Javanese Krama by Ampelgading community: the pride of having Javanese language as the mother tongue, the influence of age in mastering Javanese Krama, the fear of being considered arrogant, the courtesy in mastering Javanese Krama, and last but not least, the motivation for older generation to pass down the legacy of Javanese Krama to their children.
\end{abstract}

Keywords: Causative Factors, Language Maintenance, Javanese Krama, Ampelgading Village, Sociolinguistics

\section{Introduction}

The topic of Javanese language maintenance always sprouts from its native speakers' tendency to abandon their mother tongue, which is slowly eroding over time. It becomes evident as this attitude proliferates rapidly, not only to Javanese speakers in urban areas but also those in rural circles as well, ironically, who tend to use Indonesian instead whenever the chances. This attitude shift is very concerning, because it means both the native speakers residing either in rural or urban areas are losing their identity as Javanese. It is undeniable that there are still many people whose understanding of Javanese Krama is immaculate, but with the increasing and frequent use of Indonesian language and the developing variants of Javanese Ngoko (rough Javanese), the rural communities are also affected nonetheless. For instances, the medium of many formal events in rural communities such as meetings, social gatherings and religious events is more or less Indonesian. To actually claim the use of Indonesian within these domains not suitable is not the case, because it is a form of recognizing the existence of Indonesian as a national and union language. However, the continuous use of Indonesian in various activities by Javanese natives in rural areas will sooner or later backfire towards the survival of Javanese Krama, the language with the most refined and well-mannered speech variety of Javanese that should be protected and preserved.

The use of Javanese by the native speakers in various social activities actually has its own value to the representation of character as well as identity [1]. Shifting from Javanese to 
Indonesian in the Javanese domains has become a threat to the existence of the local language. As the result, the existence of Javanese language, which should always be the foundation of Javanese identity, is eroding over time, hence the prominence to maintain the language in order to preserve the identity that comes in unison with it. On the other hand, without abandoning other languages, the main goal is to make Javanese able to co-exist with other languages, especially Indonesian.

Based on the aforementioned situation, the researcher wants to acknowledge the factors causing the occurrence of Javanese language maintenance in the native community, especially Javanese at the Krama level. Such initiative is much needed in order to observe the existence of Javanese Krama language maintenance in the Ampelgading village that is located in the boundary area of Blitar and Malang as the community in that particular area still maintains the use of the Javanese Krama. Looking from the cultural side, this village belongs to the Mataraman cultural area even though it is located in the boundary line of Malang, which can also be referred to as Arek culture.

The overall goal of this study is to find out what factors that cause Javanese language maintenance within Ampelgading community in Blitar. Hence, the research problem is formulated as follows: What are the factors influencing the occurrence of Javanese Krama language maintenance within the Ampelgading community in Blitar?

\subsection{Ampelgading Village Community}

Administratively, the village of Ampelgading is located in Selorejo, Blitar, East Java. This village is positioned up in the hills, precisely in between the slopes of Mount Kawi and the middle of a pinery belonging to PERHUTANI (Indonesian State Forestry Company). This village is in the eastern end of Blitar. In terms of boundaries, the eastern part of the village is directly adjacent to Malang and the north is lined by Mount Kawi. While in the south, it borders the village of Sidomulyo which still belongs to the Selorejo, Malang. Then in the west it borders Kalimanis, which administratively belongs to different subdistrict called Kesamben, Blitar.

From the interviews conducted by the researchers on the locals, this village in terms of cultural aspect is of the Mataraman culture; the people are all of Javanese natives as well (residential interviews, 2020). Their daily lives heavily rely on the byproducts of farming, trading, homemade crafts business, not to mention that some of them are unskilled labors. When interacting and communicating with fellow Ampelgading residents, they use Javanese in Mataraman dialect even though the village is located on the border of Blitar and Malang.

\section{Theoretical Framework}

Multilingualism is a source of interaction in a society in which there are languages with different task variations during application in society. Furthermore, multilingualism is a phenomenon that is always present in society as a tug of war between culture and language variations that are maintained in a society [2]. In addition, this multilingualism can occur in societies consisting of those who have various ethnicities [3]. Many perspectives on the phenomenon of multilingualism emerge in the community in relation to varied forms of language and social functions that underlie the occurrence of language variants. Speakers more often use language variations in different situations. This causes each language to have the possibility of being left out depending on how often the situation related to the language is 
manifested. Language variants coexist in a multilingual society and have a certain role to play [4].

A speaker's behavior in the multilingual society generally makes use of the language's superior aspect, where they are held in high esteem by using a prestigious language variety. Language that is considered as inferior tends to be abandoned and some are even being refused to use. Many educated people encourage inferior language not to be used even though they speak it in everyday conversation. Big attention to superior language is emphasized by humans as a form of suitability for functions that overrides the ability of the criteria of a language in certain situations [4].

The variety of superior languages in a multilingual society is a language that is set as a formal standard, which is a language that tends to be spoken in social interactions and used as rules or references in the correct use of language. Writing inferior languages is difficult because of the lack of established pronunciation rules, but in many cases, very few individuals want to write in an inferior language [4].

Language maintenance is a defensive effort against the tendency of language shift. Awareness of a nation to maintain its identity is a system of values for the nation. This is needed when there is a tendency for language shift. As one of the objects of sociolinguistics studies, the phenomenon of language maintenance is very interesting to study. The concept of language maintenance is more related to the prestige of a language in the eyes of the supporting community. As exemplified by Danie that the decline in the use of several regional languages in East Minahasa is caused by the influence of the 6 Malay Manado language which has a higher prestige and the use of Bahasa Indonesia nationwide [5]. However, there are times when the first language (L1) speakers, even though the number is not that much of significance, can withstand the influence of the use of the second language (L2), which is more dominant.

Another concept is more clearly formulated by Fishman [6]. The maintenance of language in a multilingual society, on the one hand is related to the change and stability of language use and on the other hand is related to psychological, social and cultural processes. One of the issues that is quite interesting in the study of language shift and maintenance is the powerlessness of the minority migrants to maintain their native language in competition with the more dominant majority language. The powerlessness of a minority language to survive follows the same pattern. Initially it was a minor contact with the second language (L2), so that they knew two languages and became bilingual, then there was competition in the application and finally the original language (L1) shifted or even became extinct over time.

In general, schools or educational areas are often the cause of language shifts because schools always introduce second languages (L2) to students who were originally monolingual, and turned them bilingual who eventually abandoned or shifted their first language (L1) aside. Another factor which is highlighted by sociolinguistics experts is matters relating to age, sex, and frequency of contact with other languages. The study of the various cases above provides evidence that no single factor can stand alone as the sole supporter or cause of language shift and maintenance. Therefore, not all factors mentioned above must be involved in every case.

\section{Review of Related Literature}

Research on language maintenance has been explored extensively in prior studies. The first research was conducted by Sumarsono [6]. In his research report regarding the language maintenance of the Loloan Malay language in the Loloan village which belongs to the city of 
Nagara, Bali [5] there are several factors that cause the language to survive as follows: first, their settlement areas are concentrated in a place that is geographically separated from the residential areas of Bali. Second, there is tolerance from the majority of Balinese who want to use the Loloan Malay language to interact with the Loloan minority, although Balinese language remains the central medium in the conversation. Third, members of the Loloan community possesses their own religious values as Moslems which are not able to accommodate Balinese society, culture and language. Fourth, there is a high level of loyalty from the members of the Loloan community towards the Loloan Malay language as a consequence of the position or status of this language which is a symbol of the self-identity of the Muslim Loloan community; while the Balinese language is considered as a symbol of the identity of Balinese Hindus. Fifth, there is a continuous flow of language transfer by the Loloan community from the older generation to the next to preserve their mother tongue [6].

The second study was conducted by Setyaningsih [7]. In her research, the focus raised was the maintenance of the Javanese Samin in Blora. The results of the study show that Samin community tends to be loyal to the language because of their historical background, tradition or culture of Saminism, an ideology that has been embedded in their beliefs.

The third research was conducted by Ramadhanti [8]. This study was discussed about Interactional sociolinguistics. Interactional sociolinguistics is one of the approaches of discourse studies that rely on real expressions in the social context based on the views of Gumperz and Goffman. The focus of the analysis lies in the interpretation and interaction based on the relation of social meaning and linguistic meaning. The result of research indicates that the form of characteristic behavior in students' speech of Minangkabau culture background is seen from the speech given the students always pay attention to the said partner so that they can choose the right word is used in speaking. By observing the style of "Kato nan ampek" in speaking will appear character of Minangkabau people who speak with full advice, compassion, and wisdom. In addition, it shows the spirit of solidarity, caring, and a sense of responsibility in life.

Based on previous research as described above, this study utilizes similar concepts pertaining the tree previous studies which are equally focused on language maintenance. While in terms of objective, this study has many similarities with previous studies, which is to get a bigger and clearer picture of the factors influencing the maintenance of native languages. However, what distinguishes it from the two previous studies is the location of this research focus, which is on the boundary area of the community. Therefore, this study focuses on the language maintenance near the boundary region to acknowledge the maintenance factors carried out by the community where the existence of the Javanese Krama language is held in high esteem.

\section{Method}

This study has used the sociolinguistic approach. While the methodological approach used is a descriptive qualitative approach. This approach details the actual use of the language, such as the description of patterns of language/dialect usage in a particular culture by speakers, topics, and settings [5]. This is in conjunction with the statement proposed by Criper \& Widdowson [9] in that the sociolinguistic approach examines language in use, with the aim of examining language convention and its connection with other social factors in consideration.

The qualitative approach is an approach that intends to understand the phenomena about the research subjects' experiences such as the realization of behavior, perception, motivation, 
actions, etc. through the descriptive use of words and language [10]. According to Zuldafrial and Muhammad [11] was born qualitative research is a research based on descriptive data in the form of words written or oral of people or observed behavior. This qualitative research is an attempt to understand other linguistic phenomena under this particular scope. Descriptive qualitative research emphasizes understanding of problems in social life based on the conditions of reality or natural settings that are holistic, complex, and detailed [12].

Data collection was carried out by observation, interviews, documentation [13]. The listening was done by listening to the language in use. the data collected was in the form of utterances spoken by the people of Ampelgading, Selorejo, Blitar. Listening method consists of basic and advanced techniques; the former being a recording technique in which the researcher recorded individual's language usage, and the latter being free listening technique involving speech, in which the researchers were not involved directly into the conversation between natives [14]. The note taking technique as the next advanced technique was also used to collect data. The second method used in data collection was interview. The method was used to collect secondary data, that was data in the form of background information on Javanese language maintenance. The proficient method is a method of collecting data in which researchers conduct interview with the speaker of the language or informant [15]. The basic technique of this method is the provoking technique, in which researchers lure someone to talk. The advanced technique of this method is the technique of face-to-face interview, where the researcher conducts interview directly with the informant [16]. The implementation of this method was followed by the note taking technique.

The data of this study were in the form of fragments of conversation by speakers involved in various social interactions in Ampelgading. The environment studied was within the family affairs, social interaction, farms, schools, government, and other community activities. The use of language occurs naturally from natural speech events in the village community in daily communication. The data source is the subject of research [17]. The data source in this study is the conversations compiled from the people of Ampelgading, Selorejo, Blitar who use Javanese Krama.

Meanwhile, the methods used in analyzing the data of this study were through the stages (1) data reduction, (2) data presentation, and (3) data conclusions. Then to find out the factors causing it, an interpretation of the use of language and factors that cause language to occur was conducted, and (4) drawing conclusion on the maintenance of Javanese language and the factors influencing the process of language maintenance.

The respondents involved in this study were Ampelgading villagers who were conducting social interactions in various domains. Meanwhile, the object of research was Javanese Krama language, which was extensively used by the villagers.

\section{Discussion}

Language maintenance happens for some reasons, and those reasons are in fact inseparable from the way the language is preserved or maintained, in this case, the Javanese Krama language. Based on the observation, interviews, and literature studies, the maintenance of Javanese Krama language in the Ampelgading community occurred in the domains of family affairs, festivity event, neighborhood meetings, recitals, and housewives social gathering.

In the realm of the family, Javanese Krama is maintained as the consequence of its use among family members, especially parents and their children. The conversation took place by a 38-year-old mother with her 8-year-old daughter. The example is as follows: 
Mother: "Nduk, Sampeyan mpun adus?" (Daughter, have you taken a shower?).

The child answered: "Dereng, $B u$ " (Not yet, mom).

This fact shows that Javanese Krama is used or occurs in the realm of the family. Furthermore, in the realm of festivity, there was also a conversation that used Javanese Krama. It can be seen in the conversation conducted by a 68 -year-old man as follows:

The host said: "Monggo, kula aturi mlebet ing ndalem, amergi genduri sampun badhe dipun wiwiti" (Please, come in to the house, because the feast is about to begin).

Then the guests answered in unison: "Inggih” (Yes).

Then in the neighborhood meeting, there is dialogue that is carried out by adult males aged 45-50 years, there was this particular exchange:

A participant: "Bapak-bapak, monggo bilih wonteng ingkang badhe paring saran, ing rembagan menika saget mbetahaken sedaya pikiran lan asurujukan sedaya" (Gentlemen, suggestion is welcome as this meeting really needs the thoughts and approval of all).

At the meeting, there was a participant who said:

A participant: "Kula gadah usul, pripun bilih warga kedah urunan damel kas RT, supados bilih wonten kabetahan saged dipun damel kebetahanipun warga" (I have a suggestion, what if the residents are obliged to contribute to the funding to the neighborhood community that can be used in the case of emergencies).

Then the other participants answered: "Sarujuk kula kalian usulan Pak Warsito" (I agree with Mr. Warsito’s proposal).

The former conversation proves that the Ampelgading community uses Javanese Krama as a means of communication to convey their ideas and proposals.

The use of Javanese Krama was also found in the realm of religious event. At the opening of the event, it was performed by a 72-year-old man, the organizer or host said:

Host: "Maturnuwun kula aturaken dumateng the rawuh sampun ngalenggana dugi wonten dalem bapak Nasir menika satuhu dipun suwuni doa kantos waosan Yasin saha tahlil" (Thank you to all those who are willing to be present at Mr. Nasir's house to pray together to recite Yasin and Tahlil).

And finally, the use of Javanese language Krama was also encountered in the area of housewives social gathering. This is evidently done by a 40 -year-old woman with the following conversation:

A housewife: "Ing dinten menika, ingkang pikantuk arisan nggih menika Ibu Suwanti. Mekanten kula aturaken, maturnuwun" (Today, the recipient of the money is Mrs. Suwanti. Thank you). 
The excerpts or fragments of the conversation above prove that Javanese Krama is still extensively used in those particular domains. Based on the above conversations, we can draw out the factors causing the emergence of the language maintenance of Javanese Krama by the Ampelgading community. In detailed, these factors can be described as follows:

1. Javanese is the Mother Tongue

The people of Ampelgading village always use Javanese language in their daily life. This is because Javanese language is the mother tongue for the people of the village, therefore, the Javanese language atmosphere is very well pronounced in their communication. Javanese Krama is used due to its influence as the mother tongue that is always deposited in the family environment so that this attitude becomes a habit for the society to keep using the Javanese Krama.

2. The adult villagers dominate the language mastery of Javanese Krama

In general, most of Ampelgading villagers, especially middle-aged people (Between the ages of 40 and 50 years), only master Javanese. They still master Javanese Ngoko and Krama. This condition makes most of the adults in the society dominantly use Javanese especially Krama on various occasions of social interaction such as in social meetings. In addition, in the domains mentioned above, the Javanese language is generally used as a means of communication with strangers or with people whose social status is higher.

3. The fear of being considered arrogant if not speaking in Javanese Krama

In Indonesian, there is a specific proverb expressing how courteous a man is to not forget his origin: Bagai kacang lupa akan kulitnya: means someone who forgot his origins. This expression fits the effort Ampelgading community has put through in maintaining the Javanese Krama language. This is because most of them consider that people who do not use Javanese language in everyday communication will be regarded as a person who forgot the origin or is simply arrogant. For example, if there is a local-born, raised in Ampelgading moved to the city, then returned to the village and used Indonesian to communicate with other locals, then the person will be treated as arrogant. With this stereotype, parents are always encouraged to use Javanese language to communicate with their children. They also assume that their children would be able to speak Indonesian by themselves when they attend school as the language used in school is also Indonesian.

4. Javanese Krama is regarded as a form of politeness

By using the Javanese Krama in various communications, one is considered polite and appreciative of other people or interlocutors. This is because Javanese language is known to have many levels of speech. Therefore, the community considers that people who use the Javanese Krama are ethical and well-mannered.

5. Parental awareness to teach Javanese Krama to their children

Close and intimate relations among speakers, e.g., husbands and wives, lead to the use of Javanese language in daily communication. The use of Javanese language shows how close a relationship is between family members. The educational background of parents also has a specific role in supporting the matter. Parents who are aware of the importance of implanting ethics in their children's behavior will educate their children to speak in Javanese Krama, resulting in a proper communication where the children employ Javanese Krama and parents employ Javanese Ngoko. Such action is significant for children to show their respects and honor their parents in everyday interactions. 


\section{Conclusion}

Based on the results of the data analysis, it is conclusive that there are five factors that encourage the community of Ampelgading to maintain the use of Javanese Krama in their daily interactions: the pride of having Javanese language as the mother tongue, the influence of age in mastering Javanese Krama, the fear of being considered arrogant, the courtesy in mastering Javanese Krama, and last but not least, the motivation for older generation to pass down the legacy of Javanese Krama to their offspring.

\section{References}

[1] T. Mulyono and L. Triana, "Pemertahanan Bahasa Jawa pada Ranah Keluarga di Desa Munjungagung, Kecamatan Kramat, Kabupaten Tegal," Univ. Pancasakti Tegal, 2013.

[2] J. J. Gumperz, "Linguistic and Social Interaction in Two Communities," Am. Anthropol., vol. 66, no. 6 PART2, pp. 137-153, 1964.

[3] S. Ardianta, "Pengaruh Multilingualisme dalam Dunia Pendidikan terhadap Nasionalisme peserta didik dan Kaidah Bahasa Indonesia," PARAMUROBI J. Pendidik. AGAMA Islam, vol. 2, no. 2, pp. 5-13, 2019.

[4] R. Fasold, "The sociolinguistics of society. Ch. 6," Lang. Attitudes. Basil Blackwell, Oxford, 1984.

[5] A. Chaer and L. Agustina, Sosiolinguistik: perkenalan awal. Penerbit PT Rineka Cipta, 2004.

[6] Sumarsono, Sosiolinguistik. Yogyakarta: Pustaka Pelajar, 1993.

[7] N. Setyaningsih, "Pemertahanan Bahasa Bahasa Jawa Samin di Kabupaten Blora," UNDIP, Semarang, 2010.

[8] D. Ramadhanti, "Characteristic Behaviour In Students Speech With Minangkabau Cultural Setting: Interactional Sosiolinguistics Approach (Wujud Perilaku Berkarakter Dalam Tuturan Siswa Berlatar Budaya Minangkabau: Tinjauan Sosiolinguistik Interaksional)," J. Gramatika J. Penelit. Pendidik. Bhs. dan Sastra Indones., vol. 4, pp. 290-303, 2018.

[9] C. Criper and H. G. Widdowson, "Sociolinguistics and language teaching," Pap. Appl. Linguist. Edinburgh Course Appl. Linguist., vol. 2, pp. 155-217, 1975.

[10] J. Moleong, Metodelogi Penelitian Kualitatif. Bandung: Remaja Rosdakarya Offset, 2012.

[11] Zuldafrial and L. Muhammad, Penelitian Kualitatif. Surakarta: Yuma, 2012.

[12] E. Murdiyanto, "Penelitian Kualitatif (Teori dan Aplikasi disertai contoh proposal)." Lembaga Penelitian dan Pengabdian Kepada Masyarakat (LP2M) UPN" Veteran ..., 2020.

[13] Sugiyono, Metode Penelitian Kuantitatif, Kualitatif dan R\&D. Penerbit Alfabeta Bandung, 2010.

[14] M. Zaim, "Metode penelitian bahasa: Pendekatan struktural," 2014.

[15] D. P. Sudaryanto, "Metode dan aneka teknik analisis Bahasa [Method and technique of language study]." Yogyakarta: Sanata Dharma University Press, 2015.

[16] Mahsun, Metode Penelitian Bahasa. Jakarta: Raja Grasindo, 2014.

[17] M. Subana, Dasar-Dasar Penelitian Ilmiah. Bandung: CV Pustaka Setia, 2011. 